\title{
Methods of Regulation of Processes of Innovation Business Development
}

Doi:10.5901/mjss.2014.v5n12p75

Bagautdinova N.G.a

Ph.D. Galieva G.T. b

Pakhmutov Ya.0.c1

Ph.D., Pratchenko O.V. ${ }^{d}$

1Email address: verkbund@gmail.com

\section{Abstract}

The article analyses key methods of regulation of formation of most-favored-nation environment for development of innovative business, indicates their advantages and basic disadvantages which interfere effective administration of relevant processes. New approach for organization of regulation of formation of most-favored-nation for innovative business environment, as well as for utility estimate of such regulation for different types of economic agents, is offered. In conclusion the system of indicators of efficiency of most-favored-nation formation for innovative business environment management is presented.

Keywords: innovations, entrepreneurship, innovative business, regulation, administration.

\section{Introduction}

Study of key tendencies of steady development of modern global social-economic system proves raising trend of significance of business sector as the basic source of public revenue which is determined by necessity of business activities development with the aim of integral use of resource potential by implementation of complex of business characteristics focused on non-recurrent improvement of the effectiveness and innovativeness of economic development which allows to provide positive dynamics of social-economic systems in strategic perspective [1,2]. Thus, at the present stage of development innovative potential of social-economic system can be implemented on condition of formation of most-favored-nation for innovative business conditions in the format of small business enterprises which prevail in innovative economic sector which is determined by necessity to use creativity factor, as well as to provide flexibility and adaptability of relevant authorities on early stages of development [3]. As a result, necessity of development of the innovative business regulation system by creation most-favored-nation becomes especially important in modern Russian conditions.

According to data from World Economic Forum, according to the results of 2012 the status of the Russian federation in global competitiveness rating decreased for 1 position in comparison with 2011, as a result of which Russia was on the $67^{\text {th }}$ place in this rating of 144 countries $[1,4]$. Deterioration of competitiveness was caused by negative change of quality of institutions, current level of business competition on the market of goods and services, underdevelopment of financial market, while positive dynamics characterized such indicators as macroeconomic environment and infrastructure $[5,6]$. And representatives of business community say that insufficient quantity of institutions is the most significant factor that prevents activity increase in this economic sector; corruption, insufficient flexibility and efficiency of the system of governmental regulation of business, disproportionality of financial market and labor market are indirect characteristics of this factor; all this does not allow national businessmen to use favorable macroeconomic situation for the purpose of creation of stable basis of competitiveness [7].

\section{Research Methodology}

Administration of processes of innovative business development by governmental authorities being one of the key methods of formation of steady dynamics of social-economic system is implemented mainly by means of management of the structure of business entities sources of financing of innovative economic sector, as well as by means of development of the system of innovative infrastructural provision $[8,9]$. Thus, it is necessary to form the integral system of regulation 
innovative business on the basis of distinct distribution of powers and responsibilities of public management distribution [10] in the process of implementation of corresponding administration processes. Matrix of rational regulation of processes of formation of most-favored-nation environment for development of innovative business (pic. 1), in which axis of abscissa describes the current level of use of innovative regional infrastructure, and axis of ordinates describes the type of regulation of the structure of innovative business sources of finance, was formed in order to solve a problem in the frames of work.

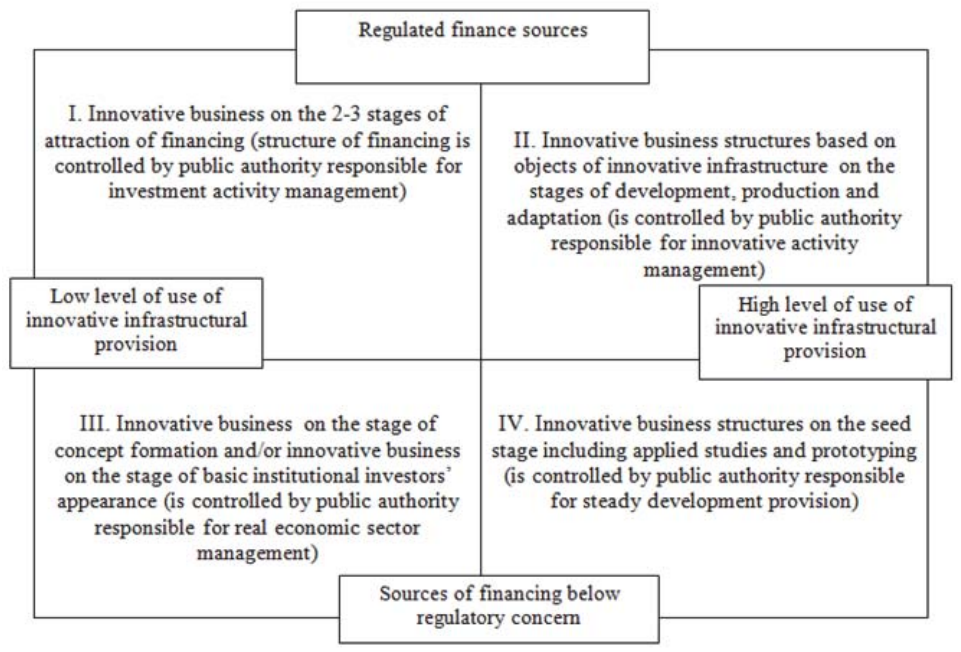

Pic. 1. Matrix of rational regulation of formation of most-favored-nation environment for development of innovative business

At that controlled sources of financing are understood to be investment resources whose usage procedure can be regulated by state run public authorities (venture capital financing, instruments of state-financing backing of innovative business, tax credits, borrowed capital); whereas the sources below regulatory concern are understood to be financial means, whose inviting and operating procedure is beyond capabilities of direct control on the side of state run public authorities and, consequently, can be subject to impact of indirect managing measures only (internal funds of innovative businessmen, means of business angel investors, financial resources provided to innovative business structures on the basis of confidence given by the closest members of social network of enterprise founders) [13].

On this picture we can see that regulation of activities of innovative business of various types on different stages of innovative cycle should be implemented by different subsystems of public administration, and in the frames of the $1^{\text {st }}$ quadrant the organization function is the prior from the point of view of ensuring efficiency of formation of most-favorednation environment, of the $2^{\text {nd }}$ quadrant - planning function, of the $3^{\text {rd }}$ quadrant - coordinating function and of the $4^{\text {th }}$ quadrant - function of motivation. Central body of executive power on corresponding level of hierarchy of social-economic system consistently regulated and controls processes of development of innovative business in social-economic sphere which coordinates activities of public authorities.

\section{Formation of Evaluation System of The Results of Small Business Regulation}

Recent research of dynamics of innovative business development in the Russian Federation performed in the frames of Global Entrepreneurship Monitor and consortium of World Bank $[5,11]$ show that difficulties that arise in the process of attracting of finance, together with administration quality and adjoint processes of state control, are major problems that greatly restricts development of innovative business on the seed stage. As a result, formation of the system of effective regulation of priority-oriented financing structure of innovative business structures on the basis of stimulation of formation of optimal financing structure for every definite stage of development of the economic entity of financing in terms of regulated sources and sources below regulatory concern, is an important task of state run public authorities in the frames of activation of innovative entrepreneurship which presupposes construction of relevant optimization function. 
Process of attracting of finance by the entity of innovative entrepreneurship from positions of provision of maximum efficiency of development of social-economic system of the innovative activity indicator presupposes formation of the following positive results:

- beneficial usefulness for enterprises of small innovative business $n_{i}$, which arises because of formed by administration methods possibility of creation and development of innovative business structure in accordance with the approved plan;

- beneficial usefulness owners of financial resources $n_{f j}$ which arises because of additional income provision and which is expressed in peculiarities of innovative business development and characteristics of corresponding innovative process by the function of independent variables of income structure analyzed on the parameter of combination of regulated income sources and sources below regulatory concern;

- $\quad$ synergetic effect $\Sigma n_{i j}$ which appears in the result of interaction of innovative businessmen and investors which will allow to provide level decrease of unforced management errors управления on early stages of development of the entity of innovative business.

Cumulative effect from attracting of regulated income sources and sources below regulatory concern for individual party of innovative business is formalized in the following way:

1) $\Pi_{i}\left(f_{j}\right)=n_{i}+n_{i j}+\sum n_{i} f_{j}$

Due to the fact that in the frames of presupposed approach the structure of financing sources is the optimization criterion, the optimal utility level that can be obtained by entity of innovative business is determined by evaluating of partial differential derivative of the expression (1) of the parameter of income structure independent variable from the point of view of combination of regulated income sources of the investor and sources below regulatory concern:

2) $\Pi_{\text {opt }}=n_{i}+\left(\left(n_{i j}+\sum n_{i j} f_{j}\right) / \partial f_{j}\right.$

Determination of utility of realization of business activity in the innovative sector is carried out by summing-up of correspondent optimal indicators with the account of sector profile of innovative business structures which allows to determine optimal structure of their financing from the point of view of combination of regulated financing resources and resources below regulatory concern; this should be taken into consideration in process of development of national and regional financial policy and financial strategy with the aim of formation of most-favored-nation for innovative business environment in national economic system and its subsystems [14, 16].

Formation of most-favored-nation environment for innovative business development on different levels of national hierarchy should include the elements of formation of optimal financial structure, as well as the elements of formation and development of optimal infrastructural provision of innovative business which will result in economic, social and institutional development of innovative economic sector in the frames of integral social-economic system. Thus, development of national strategy and tactics of regulation of innovative business should be performed with the account of dynamics and current level of corresponding three categories of indicators which presupposes necessity of formation of the system of indicators of effectiveness of management of formation of most-favored-nation environment for innovative business (table 2).

Table 2: System of indicators of effectiveness of management of formation of the most-favored-nation environment for innovative business development

\begin{tabular}{|c|c|c|}
\hline Economic indicators & Social indicators & Indicators of institutional development \\
\hline $\begin{array}{c}\text { 1. Weighted average by the parameter of } \\
\text { investment volume - investment profitability }\end{array}$ & $\begin{array}{c}\text { 1. Quantity of workplaces created in the } \\
\text { frames of innovative projects implemented in } \\
\text { the region }\end{array}$ & $\begin{array}{c}\text { 1. Average level of barriers at entrance of } \\
\text { innovative business into industry }\end{array}$ \\
\hline $\begin{array}{c}\text { 2. Weighted average by the parameter of } \\
\text { investment volume - risk level of innovative } \\
\text { projects }\end{array}$ & $\begin{array}{c}\text { 2. Dynamics of steady development of social- } \\
\text { economic system determined as weighted } \\
\text { dynamics of three components of steady } \\
\text { development }\end{array}$ & $\begin{array}{c}\text { 2. Efficiency of combination of regulated } \\
\text { financing sources and sources below } \\
\text { regulatory }\end{array}$ \\
\hline $\begin{array}{c}\text { 3. Total investment into the sector of } \\
\text { innovative business }\end{array}$ & $\begin{array}{c}\text { 3. Index of development of human potential in } \\
\text { social-economic system }\end{array}$ & $\begin{array}{c}\text { 3. Average coefficient of loading of } \\
\text { operating elements of innovative } \\
\text { structure }\end{array}$ \\
\hline $\begin{array}{c}\text { 4. Total net present value from project } \\
\text { implementation by entities of innovative } \\
\text { business in the region }\end{array}$ & $\begin{array}{l}\text { 4. Dynamics of polarization level of economic } \\
\text { space or polarization level of economic space }\end{array}$ & $\begin{array}{c}\text { 4. Output efficiency of innovative market } \\
\text { businessman calculated as average of } \\
\text { relations of business value on exit for } \\
\text { project investment }\end{array}$ \\
\hline 5. Weighted average by the parameter of & 5. Relations of average salary of 10\% most & 5. Average level of administration of \\
\hline
\end{tabular}




\begin{tabular}{|c|c|c|}
\hline $\begin{array}{c}\text { investment volume - internal rate of return } \\
\text { (IRR) in project implementation by entities of } \\
\text { innovative business in the region }\end{array}$ & $\begin{array}{c}\text { low-paid employees of real economic sector to } \\
10 \% \text { most highly-paid employees of the sector } \\
\text { in social-economic system }\end{array}$ & activity of innovative businessmen \\
\hline $\begin{array}{c}\text { 6. Weighted average by the parameter of } \\
\text { investment volume - pay-back period of } \\
\text { projects implemented by entities of innovative } \\
\text { business in region }\end{array}$ & $\begin{array}{c}\text { 6. Gini coefficient (for social-economic system } \\
\text { under consideration) }\end{array}$ & $\begin{array}{c}\text { 6. Proportion of innovative enterprises } \\
\text { existing more than 3 years to the number } \\
\text { of innovative enterprises registered for } \\
\text { period in consideration }\end{array}$ \\
\hline
\end{tabular}

The proposed system of indicators can be used with the aim of determination of attractiveness of the region from the point of view of perspectives of innovative business development. For this purpose scoring on Likert scale in the range of $1 \div 7$ is held for every indicator from table 2 , then the profile of the attractiveness of the territory for businessmen of innovative sector which allows to identify "bottlenecks" in its regulation (for example, indicators with the rate lower than average Russian level), is formed, and integral indicator of attractiveness as score which allows to make comparative analysis of attractiveness of different territories on the criteria of development of most-favored-nation environment for innovative business, is calculated.

\section{Conclusion and Recommendations}

In the research process forecasting was held on the basis of the data of the republic of Tatarstan in the frames of the following scenarios: mineral- raw materials scenario which presupposes refusal from stimulation of innovative business in the region and development mainly by means of mineral- raw-materials base; current scenario which presupposes maintenance of present tendencies of development of the region; innovative scenario which presupposes increase of efficiency of innovative business management in the region by creating most-favored-nation conditions, including by implementation of proposed in this work instruments and methods. Results of forecasting which is made on the basis of the data concerning development of enterprises of this region are presented on на ріс. 2.

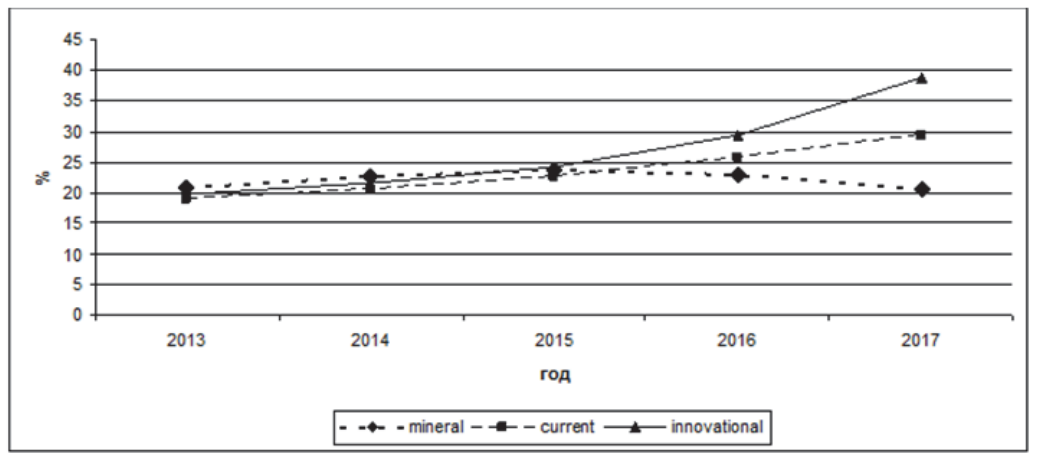

Pic. 2. Share of innovative production in GDP of the Republic of Tatarstan for 2013-2017 (forecast)

Thus, implementation of innovative scenario which intends restructuring of processes of innovative business management by formation of integral most-favored-nation environment will allow to increase the share of innovative production in GDP of the Republic of Tatarstan for 31,5\% in comparison with the current situation, and this shows the feasibility of using the suggested in the thesis research work instruments and mechanisms. It is also necessary to say that implementation of mineral- raw materials scenario can result in loss of leading position of the Republic of Tatarstan in innovative activities development because of impossibility of implementation of comprehensive approach for formation of integral most-favored-nation environment for innovative business in the frames of this scenario.

\section{References}

Acs Z., Desai S., Hessels J. Entrepreneurship, economic development and institutions. Small Business Economics, Vol. 31, No. 3, Special Issue: Entrepreneurship, Economic Development and Institutions (October 2008), pp. 219-234. World Economic Forum. http://www.weforum.org/gcr

Gainova R.A., Shaidullin R.N., Safiullin L.N. and Maratkanova E.M. Infrastructural Component in Maintenance of Competitiveness of 
Region// World Applied Sciences Journal, 27(13), 2013, pp. 97-101.

Safiullin M.R., Samigullin I.G. and Safiullin L.N. Model of Management of Competitiveness of a Machine-building Complex/l World Applied Sciences Journal, 27(13), 2013, pp. 212-216.

Ulesov D.V., Shigabieva A.M., Maratkanova E.M. and Shaidullin R.N. Information Infrastructure of Small Business Development/l World Applied Sciences Journal, 27(13), 2013, pp. 193-196.

Nystrom K. The institutions of economic freedom and entrepreneurship: evidence from panel data. Public Choice, Vol. 136, No. 3/4, Sep., 2008, pp. 269-282.

Naude W. Entrepreneurship, developing countries and developing economies: new approaches and insights. Small Business Economics, Vol. 34, No. 1, Special Issue: Entrepreneurship, Developing Countries and Development Economics Jan., 2010, pp. 1-12 Global entrepreneurship monitor. Global report 2012/ www.gemconsortium.org.

Fakhrutdinova, E., Safina, L., Kolesnikova, J., Fedor, Mikhailov. Quality formation of working life of the youth// World Applied Sciences Journal. Volume 27, Issue 13, 2013, Pages 87-91.

Glebova I.S., Rodnyansky D., Sadyrtdinov R., Khabibrakhmanova R. and Yasnitskaya Y. Evaluation of Corporate Social Responsibility of Russian Companies Based on Nonfinancial Reportingll Middle-East Journal of Scientific Research 13 (Socio-Economic Sciences and Humanities): 143-148, 2013.

Lerner J. The boulevard of broken dreams: innovation policy and entrepreneurship. Innovation Policy and the Economy, Vol. 13, No. 1, January 2013, pp. 61-82.

Ulesov D.V., Murtazina G., Safiullin L.N. and Saipullaev U.A. Special Aspects of Development of Business in the Knowledge-Based Economy //World Applied Sciences Journal, 27(13), 2013, pp. 189-192.

Safiullin, M.R., Elstin, L.A., Shakirova, A.I. (2012). Evaluation of business and economic activity as a short-term forecasting tool. Herald of the Russian Academy of Sciences, 4, 290-294.

Shaidullin R.N., Ulesov D.V., Shigabieva A.M. and Safiullin L.N. Innovative Infrastructure in Post-Industrial Society// World Applied Sciences Journal, 27(13), 2013, pp. 180-183.

Shane S., Ulrich K. Technological innovation, product development, and entrepreneurship in management science. Management Science, Vol. 50, No. 2, Feb., 2004, pp. 133-144.

Park S. Regional innovation strategies in the knowledge-based economy. GeoJournal, Vol. 53, No. 1, 2001, pp. $29-38$. 
